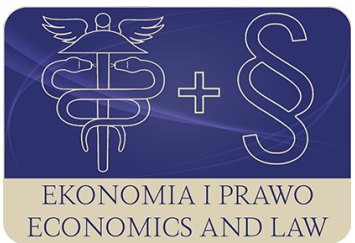

EKONOMIA I PRAWO. ECONOMICS AND LAW

Volume 15, Issue 4, December 2016

p-ISSN 1898-2255, e-ISSN 2392-1625

www.economicsandlaw.pl

ORIGINAL ARTICLE

received 29.09.2015; revised 08.07.2016; accepted 31.12.2016

Citation: Madrak-Grochowska, M. (2016). The information infrastructure of knowledge-based economies in the years 1995-2010. Ekonomia i Prawo. Ecomomics and Law, 15(4): 503-513.

doi:10.12775/EiP.2016.034.

\title{
The information infrastructure of knowledge-based economies in the years 1995-2010
}

\section{MAEGORZATA MADRAK-GROCHOWSKA}

Nicolaus Copernicus University, Faculty of Economic Sciences and Management, Department of Economics, ul. Gagarina 13A, 87-100 Toruń, Poland

$\checkmark$ madrak_grochowska@econ.umk.pl

\begin{abstract}
Aim: The objective of this article is to make a brief presentation of the information infrastructure as one of the four pillars of the knowledge-based economy (KBE). It also attempts to construct (based on taxonomic methods and applying seven diagnostic variables) a synthetic measure for assessing the degree of the development of information infrastructures in 29 KBEs in the time period 1995-2010.

Motivation: The work structure is subordinated to the so defined objective and comprises the introduction, overview, measurement and analysis of the level of the development of information infrastructure in KBEs, and a brief summary.

Results: The results of the research obtained by the author allowed the creation of four rankings of the level of the development of information infrastructure in the 29 analysed KBEs and led to the formulation of the conclusion that in the time period 1995-2010 the average level of the development of information infrastructure in the 29 economies grew steadily (with the highest values noted in highly developed KBEs), and the range of variability decreased significantly.
\end{abstract}

Keywords: information infrastructure; knowledge-based economy; taxonomic methods; information and communication technologies

JEL: O30; 039 


\section{Introduction}

Within the KBE model the broadly understood knowledge must be easily accessible, properly stored, processed efficiently and quickly distributed so that it could reach the largest possible audience - states, local governments, companies and various social groups. For this reason, it appears indispensable to base a KBE on a pillar in the form of a solid information infrastructure, being the driving force of the transformation of contemporary highly developed countries towards a new type of economy (Balcerzak, 2009, p. 71; Madrak-Grochowska, 2013, pp. 361-362; Madrak-Grochowska, 2010, p. 44).

This innovative and comprehensive information platform is understood within the KBE concept as a set of modern equipment, extensive databases, varied and competing services delivered by specialised institutions whose purpose is to provide effective communication as well as efficient processing, storage and distribution of useful information to multiple entities, while following two basic principles, i.e., providing equal opportunities in access to knowledge, and protecting intellectual property (Brzozowska \& Eatuszyńska, 2006, p. 137; Cleaver, 2003, p. 54). It is also noteworthy that this infrastructure includes not only advanced information and communication technologies (ICT), but also more traditional media. However, the most important is the fact that all of the mentioned herein elements of the information infrastructure constitute a non-contestable basis for the other three pillars of KBE (i.e., economic and institutional stimuli, human capital, and innovation system) and act as a kind of 'window on the world' for information society being shaped under a new type of economy. The condition, quality and efficiency of the created information infrastructure determine the development and efficiency of all structures created within the KBE (Lubacz, 2001, pp. 39-40) and for that reason this infrastructure has become the subject of consideration of this article.

The objective of the present article is to make a brief presentation of the information infrastructure occurring in the role of one of the four pillars of the KBE and to attempt to construct a synthetic measure for assessing the level of the development of information infrastructure in 29 KBEs in the years 1995-2010. Moreover, it is the author's intention to apply the resulting measure in the construction of four rankings of the level of the development of information infrastructure in KBEs as well as to make space-time comparisons in the scope of the complex phenomenon under study.

\section{The current state of knowledge}

As clearly follows from research conducted to date, the issue of systematic monitoring of the level of the development of information infrastructure, both in the scope of progress made in achieving access to it and in the scope of the ability of companies and individuals within societies to use its potential in practice, is increasingly significant for effective state policies of achieving 
a developed KBE. A system of twelve measures (table 1) used by the World Bank Institute within the framework of the KAM 2012 methodology proves very helpful in making a fair evaluation.

When making a synthetic evaluation of a group of measures presented in the table 1, it can be concluded that the design of an efficiently developing information infrastructure within a KBE in the first place requires undertaking many actions that are purely technical in nature. Among them it is necessary to intensify investments in infrastructure and in information and communication services whose aim would be the expansion of cellular networks and digital television, as well as the implementation of plans to 'network' fully the country and thus bring the broadband and relatively cheap Internet to all entities and sectors of the economy. The implementation of such a strategy would certainly be an unprecedented success for newly emerging KBE structures, because, as a consequence, there would be a significant increase in the Internet and new media use rate in schools, research institutions, healthcare facilities, government offices and local government and in the broadly understood business (Płowiec, 2005, p. 23; Madrak-Grochowska, 2010, pp. 45-47). In addition, as a result of taking those actions the following areas of economic, social, and public activity could develop very quickly: e-commerce, e-banking, e-learning, and e-administration.

It must be remembered, however, that the basic requirement for the implementation of all of the above tasks is conducting an efficient process of the demonopolization of the IT and telecommunications sectors, and then increasing systematically the level of competitiveness of these sectors by liberalizing conditions for market entry of new companies in the field of ICT, new providers of innovative products, services and ICT applications. It is also necessary to support the built information infrastructure with various regulatory actions, including, in particular, the development of a flexible legal framework for new forms of economic and social activities (which arose as a result of the widespread use of advanced technologies) and the creation and enforcement of the protection of personal data, intellectual property, electronic circulation of documents, electronic signature, and preventing virtual crime (Madrak-Grochowska, 2013, pp. 361-362).

It seems, however, that the most important link in the process of building a solid information infrastructure as part of a KBE is a well-developed information society, fully computerized and capable of utilizing ICT services in order to generate a significant portion of the national income (Nowak, 2005, pp.

1 The KAM 2012 methodology was developed under the World Bank Institute's Knowledge for Development Programme (K4D) as a tool for comprehensive assessment of the strengths and weaknesses of the elements that build the different pillars of the KBE in a country as well as to make comparisons with other countries or groups of countries in regions. It is an instrument easy to use with a complex structure of up to 148 measures applied to estimate the Knowledge Economy Index that characterizes the level of development of the KBE in 146 economies (World Bank, 2015b). 
39-40; Karlik, 2007, pp. 89-98). Obviously, the formation of the thus defined society within the new type of economy is closely related to general satisfaction of the needs of educating citizens (regardless of their age, sex, profession, origin and social status) in the field of efficient use of advanced technologies and modern sources of information (Ducatel et al., 1999, pp. 3-4; Cleaver, 2003, pp. 61-63). Under a KBE it is even necessary, since, on the one hand, this type of action allows limiting dangerous consequences of the phenomenon of e-exclusion, on the other hand, it contributes to the growth of 'digital literacy' rates. It seems, however, that in the matter under consideration there is a 'third side of the coin' which suggests that in the fervour of the global computerization of almost every aspect of life, it is equally important to show restraint and avoid excessive, unhealthy 'technologization' of human relationships — relationships that have always been the basis for the functioning of any society, any economy, and even the whole world.

\section{The methodology of research}

Having performed in the previous paragraph the theoretical characteristics of the information infrastructure as a pillar of the KBE, empirical analysis was commenced. Its purpose was to attempt to quantify the factors that determine the development of information infrastructure within KBEs and to construct (based on taxonomic methods and using 7 diagnostic variables) a synthetic measure of the level of the development of information infrastructure of this type of economies in the years 1995-2010. This study covered 29 countries, which, according to the author's doctoral dissertation can be regarded as being in their seed phase or being a low, medium, or highly advanced $\mathrm{KBE}^{2}$.

\section{The research process}

The first phase of the implemented taxonomic study consisted in selecting potential diagnostic variables, i.e., specifications of features which, according to the theoretical analysis performed in the previous section and substantive and formal criteria, were considered initially as essential links in a comprehensive assessment of the level of the development of information infrastructure within a KBE. Among them, due to the availability of reliable, complete and comparable statistical data, seven stimulant variables were determined that represent different aspects of information infrastructure within a KBE. The variables are presented in the table 2.

The set of potential diagnostic characteristics specified in table 2 was assessed due to the criteria of the informational value of variables. The first was

2 This study has covered the following countries: Australia, Austria, Belgium, the Czech Republic, Denmark, Estonia, Finland, France, Greece, Spain, the Netherlands, Ireland, Israel, Japan, Canada, South Korea, Germany, Norway, New Zealand, Poland, Portugal, Slovakia, Slovenia, Switzerland, Sweden, the USA, Hungary, Great Britain, and Italy. 
a demand for high spatial variability, and the value of the coefficient of variation not exceeding the limit of $15 \%$ was taken as a basis for the exclusion of the characteristics $X_{j}$ from further analysis. According to the selected threshold value, none of the characteristics was considered a quasi-fixed variable and, therefore, all were included in further analyses. Then, out of the seven variables considered their representatives were selected, with the support of the Hellwig's parametric method ${ }^{3}$ with an arbitrarily determined threshold level of correlation of $r^{*}$ equal to 0.8. In accordance with the basic criterion for this method, the characteristics $X_{2}, X_{3}, X_{5}, X_{6}$ and $X_{7}$ (which in each or in most of the analysed periods were diagnosed as either central or isolated) were classified to the set of the final variables.

In the next step the normalization process to the final diagnostic variables using the unitarisation zeroed method proceeded, which meets all of the demands set to normalization procedures with respect to characteristics ${ }^{4}$. As a result, variables with values in the range $[0 ; 1]$ were obtained, all of which had, of course, the nature of stimulants.

The last task that was performed in the process of constructing a synthetic measure of the level of the development of information infrastructure in a $\mathrm{KBE}$, was the use of a suitable additive aggregation function receiving values in the range $[0 ; 0.25]$ of the following formula:

$$
S R I I_{i}=\sum_{j} X_{i j} \cdot \omega_{j},
$$

where:

$S R I I_{i}$ - the synthetic measure of the level of the development of information infrastructures of the $i$-th $\operatorname{KBE}(i=1, \ldots, 29)$;

$x_{i j}$ - the value of the normalised variable $X_{j}$ for the $i$-th $\mathrm{KBE}$ $(i=1, \ldots, 29)$;

$\omega_{j}=1 / 20 \_$the weight assigned to the normalized variable $X_{j}{ }^{5}$.

The above aggregation formula was applied to determine the synthetic measures of the level of the information infrastructure $S R I I_{i}$ for all of the 29 countries covered by the analysis during all of the four research periods, i.e.,

${ }^{3}$ For more details about the Hellwig's parametric method see Hellwig (1981, pp. 4668).

${ }^{4}$ For more details about the zeroed unitarisation method and the demands posed to the characteristics normalisation see Kukuła (2000).

5 The author of this article, referring to the concept of the sustainable development of the pillars of the KBE, assumed the principle that each of the four pillars of this type of economy has an equal, i.e., 25\%, stake in the construction of a KBE, and every characteristics - in relation to the pillar - has the same validity status. For this reason, when researching each of the five final variables representing information infrastructure in a KBE, the author assumed for the construction of aggregate measure the weight $\omega_{j}$ equal to $1 / 20$ (i.e. $1 / 4 \div 5$ variables). 
the years 1995, 2000, 2005, and 2010. The results of these calculations along with the rankings based on them, in which the higher the position of a given state, the larger the value of the measure $S R I I_{i}$, are contained in table 3.

\section{The results of research}

Analysing individual rankings presented in table 3, it can be seen that in each period of research the highest level of information infrastructure occurred in the following countries: the USA, Switzerland, Ireland, Sweden, the Netherlands, Denmark, and Finland. These are economies that are generally recognized as the most advanced KBEs. The serious underdevelopment of this infrastructure, in turn, was noted in Greece, Poland, Portugal, Spain, and Slovenia these are the countries that represent only the seed phase of a KBE. One can, therefore, conclude that the rate of the evolution of economies towards the KBE and the achieved stages of the advancement of the KBE in the years 1995-2010 were very strongly determined by the level of the development of information infrastructure in the countries concerned, thus confirming that this infrastructure is one of the key driving forces of KBEs and its absence can be a serious impediment to growth for these types of economies.

Enriching the above conclusions by the analysis of selected descriptive characteristics of the synthetic measure $S R I I_{i}$ shown in table 4, and considering the data contained in the box plot below, it can be stated that in the studied years, the average level of the development of information infrastructure in the 29 KBEs surveyed generally grew steadily, which is of course a positive phenomenon. This conclusion is confirmed by the measures of the central tendency that from period to period were achieving higher and higher values.

As can be read from the data contained in table 4 and chart 1 , the level of information infrastructure in the 29 KBEs considered was characterised by quite a high degree of differentiation in the years 1995-2010. The weakness described herein (often associated with the concept of the so-called information or technology gap) can be seen clearly when analysing the relatively high value of the range, standard deviation and coefficient of variation. It should be noted, however, that during the period under study the scope of that diversity decreased considerably, and the economies decisively moved closer to each other in terms of the development of their information infrastructures, which should be looked upon as a positive phenomenon.

At this point attention should be paid to the asymmetry in the distribution of the synthetic measure $S R I I_{i}$ (table 4). This distribution was (except for 1995), left-asymmetric, pointing to the fact that the vast majority of the countries examined had higher values of the aggregate variable describing the development of information infrastructure in a KBE than the arithmetic average. Additionally, the left-sided asymmetry observed grew in strength from period to period, proving that also in this matter we can see a kind of catch-up and convergence process. 


\section{Conclusion}

The theoretical and empirical analysis carried out in this article points to the fact that the process of building information infrastructure as a reliable pillar of the KBE is a complex process, arduous and difficult to implement, both from the point of view of financing related activities, as well as due to the need to overcome many often very serious structural, legal, technical, and mental barriers. On the other hand, the outcome of the research presented in the present article proves that the efforts in creating and strengthening this infrastructure in an economy translates into long-term tangible benefits related to, among others, a high socio-economic development, competitive advantage and dominance in the international arena. Such countries as the United States, Switzerland, Ireland, Sweden, the Netherlands, Denmark and Finland serve a good example proving the thesis and they are commonly recognized as the most advanced KBEs. In the taxonomic research presented in the article, those countries represented the highest levels of the development of information infrastructure. Moreover, one can conclude that there is no other way for KBEs as a continuous development of their information infrastructure. This rule seems to be proved by the economies considered in the work which in the years 1995-2010 were characterized by a steadily increasing average level of the development of information infrastructure, a decreasing scope of volatility, and by an increasingly stronger left-sided asymmetry, which should be read as desirable phenomena.

\section{References}

Balcerzak, A.P. (2009). Państwo w realiach „nowej gospodarki”. Podstawy efektywnej polityki gospodarczej w XXI wieku. Torun: Wydawnictwo Adam Marszałek.

Brzozowska, K., \& Łatuszyńska, M. (2006). Infrastruktura informacyjna jako element infrastruktury publicznej (próba systematyzacji). In K. WłodarczykŚpiewak (Ed.), Wybrane problemy gospodarki opartej na wiedzy. Szczecin: Katedra Mikroekonomii Uniwersytetu Szczecińskiego.

Cleaver, K. (2003). Wstępna strategia tworzenia gospodarki opartej na wiedzy w krajach przystępujących do Unii Europejskiej. In A. Kukliński (Ed.), Gospodarka oparta na wiedzy. Perspektywy Banku Światowego. Warszawa: Rewasz.

Ducatel, K., Burgelman, J.C., Howells, J., Bohlin, E., \& Ottitsch, M. (1999). Information and Communication Technologies and the Information Society Panel Report. Retrieved 30.12.2016 from http://ftp.jrc.es/EURdoc/eurl8730en. pdf.

Hellwig, Z. (1981). Wielowymiarowa analiza porównawcza i jej zastosowanie w badaniach wielocechowych obiektów gospodarczych. In W. Welfe (Ed.), Metody i modele ekonomiczno-matematyczne $w$ doskonaleniu zarządzania gospodarką socjalistyczną. Warszawa: PWE. 
Karlik, M. (2007). Społeczeństwo informacyjne w globalnej przestrzeni. In E. Okoń-Horodyńska (Ed.), Cztowiek i spoteczeństwo w obliczu globalizacji. Kraków: Wydawnictwo UJ.

Kukuła, K. (2000). Metoda unitaryzacji zerowanej. Warszawa: PWN.

Lubacz, J. (2001). Rozwój infrastruktury informacyjnej, In W. Cellary (Ed.), Raport o Rozwoju Spotecznym - Polska 2001. Polska $w$ drodze do globalnego spoteczeństwa informacyjnego. Warszawa: UNDP.

Madrak-Grochowska, M. (2010). Filary polskiej gospodarki opartej na wiedzy. In A.P. Balcerzak, \& E. Rogalska (Eds.), Stymulowanie innowacyjności i konkurencyjności przedsiębiorstwa w otoczeniu globalnej gospodarki wiedzy. Toruń: Wydawnictwo UMK.

Madrak-Grochowska, M. (2013). Konkurencyjność gospodarek opartych na wiedzy. Propozycja pomiaru. Ekonomia i Prawo, 12(3). doi:10.12775/ EiP.2013.027.

Nowak, J.S. (2005). Społeczeństwo informacyjne - geneza i definicje. In G. Bliźniuk, \& J.S. Nowak (Eds.), Spoteczeństwo informacyjne 2005. Katowice: Polskie Towarzystwo Informatyczne Oddział Górnośląski.

Płowiec, U. (2005). Kierunki działań przyjęte w Strategii Lizbońskiej. In E. Okoń-Horodyńska, \& K. Piech (Eds.), Strategia Lizbońska a możliwości budowania gospodarki opartej na wiedzy w Polsce - wnioski i rekomendacje. Warszawa: PTE.

World Bank. (2015a). Database. Retrieved 18.05.2015 from http://web.worldbank.org.

World Bank. (2015b). Knowledge Assessment Methodology. Retrieved 18.05.2015 from http://web.worldbank.org.

\section{Acknowledgements}

Author contributions: author have given approval to the final version of the article. 


\section{Appendix}

Table 1 .

The measures of information infrastructure applied within the KAM 2012 method

\begin{tabular}{cc}
\hline Name of measure & Unit (scale) \\
\hline total telephones per 1,000 people & number \\
total landline telephones per 1,000 people & number \\
total cellular telephones per 1,000 people & number \\
computers per 1,000 people & number \\
percentage of households with TV sets & $\%$ \\
total newspapers per l,000 people & number \\
international Internet connections & bits per person \\
internet users per 1,000 people & number of people \\
average monthly spending on the Internet & USD \\
access to e-administration services & {$[1 ; 7]$} \\
the quality of e-administration services & {$[1 ; 7]$} \\
of GDP & $\%$
\end{tabular}

Source: own study based on the data derived World Bank (2015a).

Table 2.

Potential diagnostic variables selected for measuring the level of the information infrastructure in 29 KBEs throughout the time period 1995-2010

\begin{tabular}{cc}
\hline Symbol & Name of potential diagnostic variable (unit/scale) \\
\hline$X_{1}$ & total telephones per 100 people (number) \\
$X_{2}$ & total computers per l,000 people (number) \\
$X_{3}$ & internet users per 100 people (number) \\
$X_{4}$ & percentage of exports of ICT goods in total exports of goods (\%) \\
$X_{5}$ & percentage of imports of ICT goods in total imports of goods (\%) \\
$X_{6}$ & percentage of exports of ICT services in total exports of services (\%) \\
$X_{7}$ & expenditure on ICT goods and services as a percentage of GDP (\%) \\
\hline
\end{tabular}

Source: own elaboration. 
Table 3.

Rankings of 29 KBEs showing the development of information infrastructure in the time period 1995-2010

\begin{tabular}{|c|c|c|c|c|c|c|c|c|}
\hline \multirow{2}{*}{ Position } & \multicolumn{2}{|c|}{1995} & \multicolumn{2}{|c|}{2000} & \multicolumn{2}{|c|}{2005} & \multicolumn{2}{|c|}{2010} \\
\hline & Country & SRII $_{i}$ & Country & SRII $_{i}$ & Country & SRII $_{i}$ & Country & SRII $_{i}$ \\
\hline 1 & US & 0.1672 & $\mathrm{CH}$ & 0.1719 & $\mathrm{CH}$ & 0.1606 & NL & 0.1570 \\
\hline 2 & IE & 0.1570 & IE & 0.1610 & DK & 0.1591 & FI & 0.1480 \\
\hline 3 & FI & 0.1489 & US & 0.1501 & NL & 0.1587 & $\mathrm{CA}$ & 0.1463 \\
\hline 4 & $\mathrm{CH}$ & 0.1283 & DK & 0.1410 & SE & 0.1554 & SE & 0.1441 \\
\hline 5 & SE & 0.1269 & $\mathrm{NZ}$ & 0.1376 & IE & 0.1503 & $\mathrm{IE}$ & 0.1429 \\
\hline 6 & DK & 0.1227 & SE & 0.1372 & US & 0.1499 & $\mathrm{CH}$ & 0.1420 \\
\hline 7 & $\mathrm{NL}$ & 0.1104 & $\mathrm{AU}$ & 0.1333 & FI & 0.1363 & $\mathrm{KR}$ & 0.1406 \\
\hline 8 & GB & 0.1100 & NL & 0.1303 & IL & 0.1359 & GB & 0.1398 \\
\hline 9 & $\mathrm{NZ}$ & 0.1032 & $\mathrm{CA}$ & 0.1299 & GB & 0.1340 & US & 0.1354 \\
\hline 10 & NO & 0.1024 & $\mathrm{KR}$ & 0.1286 & NZ & 0.1268 & SK & 0.1293 \\
\hline 11 & $\mathrm{AU}$ & 0.1005 & FI & 0.1196 & $\mathrm{CA}$ & 0.1253 & DK & 0.1261 \\
\hline 12 & $\mathrm{CA}$ & 0.0978 & IL & 0.1127 & $\mathrm{KR}$ & 0.1251 & $\mathrm{JP}$ & 0.1187 \\
\hline 13 & JP & 0.0760 & GB & 0.1101 & $\mathrm{JP}$ & 0.1207 & $\mathrm{DE}$ & 0.1146 \\
\hline 14 & $\mathrm{BE}$ & 0.0759 & $\mathrm{JP}$ & 0.1068 & AU & 0.1185 & $\mathrm{CZ}$ & 0.1137 \\
\hline 15 & $\mathrm{DE}$ & 0.0719 & $\mathrm{NO}$ & 0.0955 & $\mathrm{DE}$ & 0.1166 & $\mathrm{HU}$ & 0.1132 \\
\hline 16 & IL & 0.0705 & $\mathrm{DE}$ & 0.0925 & $\mathrm{EE}$ & 0.1138 & $\mathrm{AU}$ & 0.1059 \\
\hline 17 & FR & 0.0655 & AT & 0.0899 & NO & 0.1102 & IL & 0.1052 \\
\hline 18 & AT & 0.0546 & $\mathrm{BE}$ & 0.0758 & AT & 0.0943 & $\mathrm{NO}$ & 0.1030 \\
\hline 19 & $\mathrm{CZ}$ & 0.0542 & FR & 0.0688 & FR & 0.0854 & FR & 0.0999 \\
\hline 20 & $\mathrm{KR}$ & 0.0526 & $\mathrm{HU}$ & 0.0625 & $\mathrm{HU}$ & 0.0802 & $\mathrm{EE}$ & 0.0987 \\
\hline 21 & SK & 0.0409 & $\mathrm{EE}$ & 0.0598 & $\mathrm{BE}$ & 0.0791 & $\mathrm{NZ}$ & 0.0977 \\
\hline 22 & PT & 0.0395 & IT & 0.0557 & SK & 0.0786 & $\mathrm{BE}$ & 0.0870 \\
\hline 23 & EE & 0.0393 & $\mathrm{CZ}$ & 0.0498 & $\mathrm{CZ}$ & 0.0784 & AT & 0.0823 \\
\hline 24 & IT & 0.0333 & SI & 0.0407 & ES & 0.0503 & SI & 0.0736 \\
\hline 25 & ES & 0.0296 & SK & 0.0387 & IT & 0.0462 & ES & 0.0686 \\
\hline 26 & $\mathrm{HU}$ & 0.0281 & PT & 0.0369 & SI & 0.0462 & IT & 0.0643 \\
\hline 27 & SI & 0.0279 & ES & 0.0263 & PL & 0.0395 & PL & 0.0577 \\
\hline 28 & GR & 0.0188 & PL & 0.0263 & PT & 0.0375 & PT & 0.0494 \\
\hline 29 & $\mathrm{PL}$ & 0.0104 & GR & 0.0251 & GR & 0.0123 & GR & 0.0136 \\
\hline
\end{tabular}

Notes: US — United States IE — Ireland, FI — Finland, CH — Switzerland, SE - Sweden, DK — Denmark, NL - Netherlands, GB — Great Britain, NZ - New Zealand, NO - Norway, AU — Australia, CA — Canada, JP - Japan, BE - Belgium, DE - Germany, IL - Israel, FR - France, AT - Austria, CZ - Czech Republic, KR — South Korea, SK - Slovakia, PT - Portugal, EE - Estonia, IT — Italy, ES - Spain, HU - Hungary, SI - Slovenia, GR — Greece, PL — Poland.

Source: own calculations. 
Table 4.

Descriptive characteristics for the synthetic measure SRII in the years 1995-2010

\begin{tabular}{cccrr}
\hline $\begin{array}{c}\text { Descriptive character- } \\
\text { istics }\end{array}$ & \multicolumn{2}{l}{2095} & 2005 & 2010 \\
\hline Arithmetic average & 0.0781 & 0.0936 & 0.1043 & 0.1075 \\
Median & 0.0719 & 0.0955 & 0.1166 & 0.1132 \\
First quartile & 0.0395 & 0.0557 & 0.0786 & 0.0870 \\
Third quartile & 0.1100 & 0.1303 & 0.1359 & 0.1398 \\
Minimum & 0.0104 & 0.0251 & 0.0123 & 0.0136 \\
Maximum & 0.1672 & 0.1719 & 0.1606 & 0.1570 \\
Range & 0.1568 & 0.1468 & 0.1483 & 0.1433 \\
Standard deviation & 0.0440 & 0.0448 & 0.0426 & 0.0348 \\
Variation coefficient & $56.32 \%$ & $47.82 \%$ & $40.81 \%$ & $32.34 \%$ \\
Asymmetry coefficient & 0.3303 & -0.0688 & -0.4532 & -0.7089 \\
\hline
\end{tabular}

Source: own calculations based on the data contained in table 3 .

Chart 1.

Selected descriptive characteristics for the synthetic measure $S R I I_{i}$ in the years 1995-2010

0.20

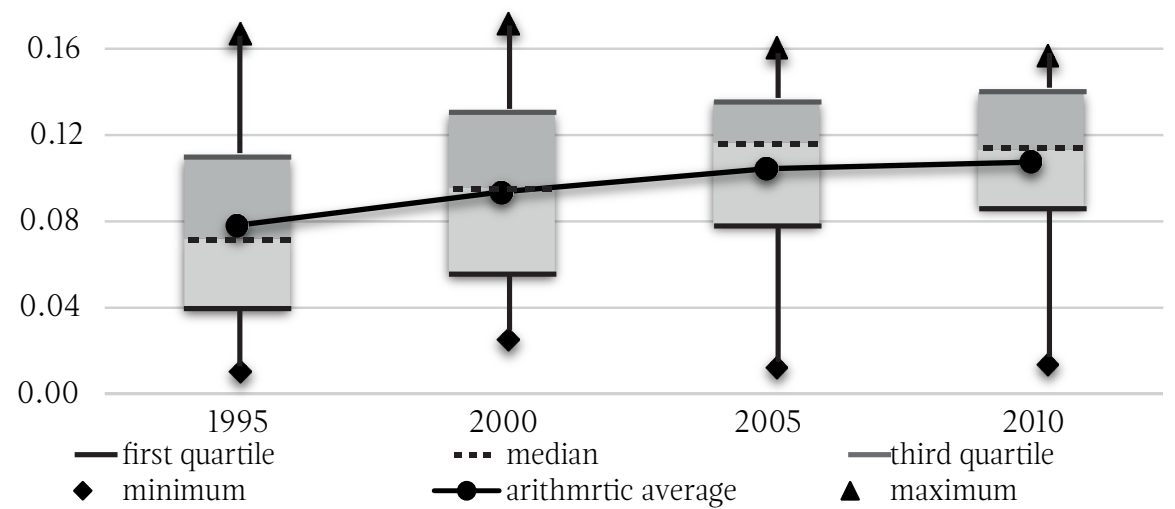

Source: own elaboration based on the data contained in table 4 . 
